\title{
Role of prenatal undernutrition in the expression of serotonin, dopamine and leptin receptors in adult mice: Implications of food intake
}

\author{
LETICIA MANUEL-APOLINAR ${ }^{1}$, LUISA ROCHA ${ }^{2}$, LETICIA DAMASIO ${ }^{1}$, \\ EMILIANO TESORO-CRUZ ${ }^{3,4}$ and ARTURO ZARATE ${ }^{1}$
}

${ }^{1}$ Endocrine Research Unit, National Medical Center, Mexican Social Security Institute; ${ }^{2}$ Department of Pharmacobiology,
Center for Research and Advanced Studies; ${ }^{3}$ Department of Research and Animal Facility, INCMN;
${ }^{4}$ Immunology Research Unit, National Medical Center, Mexican Social Security Institute, Mexico City, Mexico

Received May 15, 2013; Accepted November 11, 2013

DOI: $10.3892 / \mathrm{mmr} .2013 .1853$

\begin{abstract}
Perturbations in the levels of serotonin expression have a significant impact on behavior and have been implicated in the pathogenesis of several neuropsychiatric disorders including anxiety, mood and appetite. Fetal programming is a risk factor for the development of metabolic diseases during adulthood. Moreover, previous studies have shown that serotonin (5-HT), dopamine and leptin are important in energy balance. In the present study, the impact of maternal malnutrition-induced prenatal undernutrition (UN) was investigated in mice and the expression of 5-HT ${ }_{1 \mathrm{~A}}$, dopamine (D)1, D2 and Ob-Rb receptors was analyzed in the hypothalamus during adulthood. The UN group showed a low birth weight compared with the control group. With regard to receptor expression, $5-\mathrm{HT}_{1 \mathrm{~A}}$ in the UN group was increased in the hypothalamus and D1 was reduced, whereas D2 showed an increase from postnatal day (P)14 in the arcuate nucleus. $\mathrm{Ob}-\mathrm{Rb}$ receptor expression was increased in the hypothalamus at P14 and P90. These observations indicated that maternal caloric restriction programs a postnatal body weight gain in offspring with an increased food intake in early postnatal life which continues into adulthood. In addition, UN in mice was found to be affected by $\mathrm{Ob}-\mathrm{Rb}, 5-\mathrm{HT}_{1 \mathrm{~A}}$ and $\mathrm{D} 1 / 2$ receptor expression, indicating that these observations may be associated with hyperphagia and obesity.
\end{abstract}

Correspondence to: Dr Leticia Manuel Apolinar, Endocrine Research Unit, National Medical Center, Mexican Social Security Institute, Av. Cuauhtemoc 330, Col. Doctores, Mexico City 06720, Mexico

E-mail: letymanu@yahoo.com.mx

Key words: prenatal undernutrition, food intake, obesity, leptin, serotonin, dopamine receptors

\section{Introduction}

The fetal programming hypothesis suggests that diseases of the fetus originate through adaptation, which occurs with fetal undernutrition (UN). These adaptations may be vascular, metabolic or endocrinological and permanently change the function and structure of the body in adult life.

In a previous study, Barker et al suggested that infants with low birth weight (LBW) had an increased risk of developing obesity, hypertension and diabetes (1). Population studies and animal models have revealed critical periods when offspring are most vulnerable to environmental effects, including maternal nutritional imbalance $(2,3)$. Thus, fetal programming is considered to be a potential mechanism contributing to the development of obesity. In rats, malnutrition during select periods of pregnancy causes LBW in newborns (4).

When newborns were fed ad libitum, growth-restricted offspring demonstrated accelerated growth, currently termed 'catch-up growth' (5), such that their body weight exceeded that of the control groups (6-8). Therefore, evidence exists that early postnatal growth acceleration, which is normally considered necessary, may exacerbate metabolic dysfunction during later life (9). Moreover, excessive food intake and subsequent obesity increase the risk of developing chronic diseases. Thus, fetal programming may modify appetite-regulating hormones and neurotransmitters in undernourished newborns (9). Findings of previous studies have revealed that serotonin $(5-\mathrm{HT})$ is a neurotransmitter that also acts as an important hormone in an increasing number of physiological processes outside of the brain. Thus, serotonergic and dopaminergic receptors (D) may be targets for the treatment of cognitive deficits and feeding disorders. This vulnerability may result from abnormalities in the development and integration of serotonergic and dopaminergic projections during the prenatal period $(10,11)$.

Therefore, the aim of the present study was to determine whether prenatal UN modified the expression of the $5-\mathrm{HT}_{1 \mathrm{~A}}$, $\mathrm{D} 1, \mathrm{D} 2$ and $\mathrm{Ob}-\mathrm{Rb}$ receptors in the hypothalamus of adult mice. 


\section{Materials and methods}

Animals. The present study utilized a model of fetal programming via maternal malnutrition, in which $50 \%$ of food was restricted during pregnancy to produce LBW in the offspring (12). The protocol was approved by the Local Animal Research Committee and was conducted in accordance with the American Association for Accreditation of Laboratory Care and National Institutes of Health guidelines. Animals were assigned to one of two nutritional groups: i) Control (C) group, fed ad libitum during gestation; and ii) UN group, fed with a $50 \%$ food-restricted diet during the final week of gestation. The day of birth was designated as postnatal day $(\mathrm{P}) 0$. Following birth, offspring were weighed and litter sizes were normalized to eight offspring per litter for adequate and standardized nutrition until weaning. For the offspring study, animals were immediately classified into either the UN group, where mothers received the restricted diet during the last gestation week or to the $\mathrm{C}$ group, as aforementioned. Mothers from $\mathrm{UN}$ and $\mathrm{C}$ pups were fed ad libitum during lactation. Each litter from the two groups was weighed weekly. The first weight was recorded at $\mathrm{P} 0$ and subsequent weights were taken at P7 and P14, until P90. In the period following weaning, food intake was monitored in the $\mathrm{UN}$ and $\mathrm{C}$ offspring from the post-weaning period to P90. Offspring were sacrificed at various postnatal ages by rapid decapitation.

RNA extraction. Hypothalamic studies were performed at P0, P14 and P90. Pups were sacrificed by decapitation and brains were rapidly removed and blotted free of excess blood. Sections of the hypothalamus were removed from each group, rapidly frozen in dry ice and stored at $-70^{\circ} \mathrm{C}$ until use for RNA extraction.

Total cellular RNA was isolated from the hypothalamic tissue using TRIzol reagent in $100 \mathrm{mg}$ tissue according to the manufacturer's instructions. Briefly, RNA was precipitated from the TRIzol solution following the addition of chloroform followed by isopropyl alcohol and then washed in $75 \%$ ethanol in diethyl pyrocarbonate-treated water (DEPC). The ethanol was then removed and the RNA pellets were air-dried prior to the addition of $20 \mu 1$ RNase-free water. To remove contaminating DNA, the samples were treated with DNAase. Total RNA concentration was determined spectrophotometrically at $260 / 280 \mathrm{~nm}$, and the isolated RNA was stored at $-70^{\circ} \mathrm{C}$.

Reverse transcription-polymerase chain reaction (RT-PCR) analysis of the $\mathrm{Ob}-\mathrm{Rb}$ receptor. Purified total RNA ( $2 \mu \mathrm{g})$ was used as a template to generate first-strand cDNA (Fermentas First-Strand cDNA kit; Thermo Fisher Scientific, Waltham, MA, USA) which was amplified with a specific primer for $\mathrm{Ob}-\mathrm{Rb}$ receptor and tubulin using a Fermentas Pyrostart RT-PCR kit (Thermo Fisher Scientific). The PCR mixture contained Taq DNA polymerase and buffers (PCR amplification buffer with $30 \mathrm{mM} \mathrm{MgCl}$ ), and $10 \mathrm{mM} \mathrm{dNTP}$, and $15 \mu \mathrm{M}$ each of the $5^{\prime}$ and $3^{\prime}$ primers against the $\mathrm{Ob}-\mathrm{Rb}$ receptor were added to cDNA samples generated from the hypothalamus samples. Primers used for the $\mathrm{Ob}-\mathrm{Rb}$ receptor were: Forward: 5'-CCAGGTGAGGAGCAAGAGAC-3' and reverse: 5'-CTGCACAGTGCTTCCCACTA-3' (product size, 470 bp); $\beta$-tubulin, forward: 5'-TCAGCGTGGTGCCCTCAC-3' and reverse: 5'-GTGAGCTCAGGCACCGTC-3' (product size, $370 \mathrm{bp}$ ). Initial denaturation at $95^{\circ} \mathrm{C}$ for $5 \mathrm{~min}$ was followed by 35 cycles of denaturation for $1 \mathrm{~min}$ at $95^{\circ} \mathrm{C}$, annealing for $1 \mathrm{~min}$ at $55^{\circ} \mathrm{C}$ and extension for $1 \mathrm{~min}$ at $72^{\circ} \mathrm{C}$. PCR was terminated by a final extension at $72^{\circ} \mathrm{C}$ for 5 min using a Mastercycler ep gradient $\mathrm{S}$ thermocycler (Eppendorf, Hauppauge, NY, USA). Subsequent assay results were analyzed relative to a housekeeping gene (tubulin) within the same sample to normalize for possible variations in RNA quality, quantity and efficiency. Tubulin levels were analyzed independently and did not vary in any of the experimental groups.

Electrophoresis. The samples were separated in $2 \%$ agarose gels in the presence of ethidium bromide. The optical density (OD) of bands was measured using a Kodak Transilluminator Gel Logic 200 (Kodak, Rochester, NY, USA). Data are presented as a ratio of leptin receptor expression to tubulin.

Autoradiography. Animals were sacrificed and whole brains were rapidly removed, blotted free of excess blood, rapidly frozen in pulverized dry ice and stored at $-70^{\circ} \mathrm{C}$ for later use. For 5- $\mathrm{HT}_{1 \mathrm{~A}}$, D1 and D2 receptor autoradiography, brains were sliced into coronal sections on a cryostat (CM 1510; Leica Camera AG, Solms, Germany) at $-20^{\circ} \mathrm{C}$, each with a section thickness of $20 \mu \mathrm{m}$. Sections were thaw-mounted on gelatin-coated slides and stored at $-70^{\circ} \mathrm{C}$ in plastic bags until the day of incubation. The tissue was rehydrated at room temperature only during ligand incubation. Standard conditions were used, for example the concentration of tritium ligand (equivalent to its $\mathrm{kDa}$ ) and the concentration of ligand for non-specific binding, temperature, incubation time and washing time.

For autoradiography studies, the incubation experiments consisted of tissue sections pre-incubated in Coplin jars at room temperature in $40 \mathrm{ml}$ of a solution of Tris- $\mathrm{HCl}(\mathrm{pH}$ 7.4) incubation buffers. Tissue sections were then incubated in the same buffer containing the radioligand at an adequate final concentration. Non-specific binding was generated by the addition of butaclamol $(1 \mu \mathrm{M})$ for D1 and D2 and WAY100635 $(10 \mu \mathrm{M})$ for $5-\mathrm{HT}_{1 \mathrm{~A}}$. Following incubation, the sections were washed in ice-cold $\left(4^{\circ} \mathrm{C}\right)$ buffer solution twice for $5 \mathrm{~min}$ and immediately dipped into cold distilled water to remove any salts. Tissue sections were dried under a gentle stream of cool air. Slides were arrayed in X-ray cassettes together with tritium standards (Amersham Pharmacia Biotech, Piscataway, NJ, USA) and were exposed to tritium-sensitive film (Kodak hyperfilm; Eastman Kodak) at room temperature for 2 or 3 months (13-15). Films were developed and fixed at room temperature (Table I). ODs of the selected areas appeared on autoradiograms where these were determined using a video-computer enhancement program (Jandel video analysis software; Jandel Scientific, Corte Madera, CA, USA) and the OD values were transformed into receptor density values expressed as fmol/mg protein. Results were obtained from 10 animals per group. Brain areas and nuclei were identified using the Paxinos and Watson atlas.

Statistical analysis. Data are presented as mean \pm SEM. Differences between groups were considered statistically significant based on one-way ANOVA followed by a parametric 
multiple comparison (Tukey's test). Statistical analyses were performed using Prism Software (Graph Pad Prism 5 for Windows, San Diego, CA, USA). $\mathrm{P}<0.05$ was considered to indicate a statistically significant difference.

\section{Results}

Growth. As a result of food restriction during gestation, body weights of the UN group at birth were lower than those of the $\mathrm{C}$ group $(1.10 \pm 0.12$ vs. $1.52 \pm 0.13 \mathrm{~g} ; \mathrm{n}=10 ; \mathrm{P}<0.01)$ with a $17 \%$ reduction in body weight. The subsequent growth pattern showed 'catch-up growth' in the UN group. Thus, although there was no difference in body weight at $\mathrm{P} 14$ in the UN group compared with the $\mathrm{C}$ group (7.5 \pm 0.4 vs. $6.8 \pm 0.3 \mathrm{~g} ; \mathrm{n}=10$; $\mathrm{P}>0.1$ ) (Fig. 1), offspring from the UN group showed a significant increase in body weight compared with the $\mathrm{C}$ group at P90 (UN, 28 \pm 1 g; C, 23 \pm 1.7 g; n=10; P<0.01) (Fig. 1). Weight was increased in the UN group ( $>20 \%)$ compared with the $\mathrm{C}$ group at $\mathrm{P} 90$.

Food intake. Food intake was monitored following weaning in the offspring from the UN group compared with the $\mathrm{C}$ group and increased food intake was noted in the UN group. In early postnatal life, the UN group continued with weight gain and this trend of hyperphagia persisted throughout adult life. Food intake was significantly increased in the UN group compared with the $\mathrm{C}$ group offspring in adulthood at $\mathrm{P} 90$ ( $\mathrm{P}<0.05 ;$ Fig. 2$)$.

$O b$-Rb leptin receptor expression. In the UN group, a significant increase in the $\mathrm{Ob}-\mathrm{Rb}$ receptor expression was observed in the hypothalamus at $\mathrm{P} 14(\mathrm{P}<0.01)$ and $\mathrm{P} 90(\mathrm{P}<0.01)($ Fig. 3).

Effects of prenatal UN on 5-HT $T_{1 A}$ and D1 and D2 receptor expression in the hypothalamus. Comparison of the UN group with the $\mathrm{C}$ group at $\mathrm{P} 14$ revealed that the $5-\mathrm{HT}_{1 \mathrm{~A}}$ receptor was increased in the ventromedial nucleus of the hypothalamus (VMH; $+84 \% ; 289 \pm 18$ vs. $157 \pm 7 ; \mathrm{P}<0.001)$, in the medial preoptic area (MPA; $+56 \% ; 277 \pm 2$ vs. $177 \pm 10 ; \mathrm{P}<0.001)$ and the lateral area of the hypothalamus (LHA; $+251 \% ; 239 \pm 22$ vs. $68 \pm 2 ; \mathrm{P}<0.001)$. At $\mathrm{P} 90$, the $\mathrm{UN}$ group had an increase in the dorsal hypothalamic area ( $+64 \% ; 87 \pm 13$ vs. $53 \pm 9 ; \mathrm{P}<0.01)$, VMH (+293\%; $236 \pm 42$ vs. $60 \pm 22$; P $<0.001)$, LHA (+279\%; $220 \pm 26$ vs. $58 \pm 13 ; \mathrm{P}<0.001$ ) and arcuate nucleus (ARC; $+273 \%$; $228 \pm 62$ vs. $61 \pm 16$; $\mathrm{P}<0.001$ ) (Fig. $4 \mathrm{~A}$ and B).

In the UN group at P14, a decrease in D1 receptor expression was observed in the MPA $(-58 \% ; 27 \pm 3$ vs. $64 \pm 2 ; \mathrm{P}<0.001)$, VMH $(-13 \% ; 60 \pm 1$ vs. $69 \pm 3 ; \mathrm{P}<0.05)$, ARC $(-37 \% ; 53 \pm 6$ vs. $84 \pm 4$; $\mathrm{P}<0.001)$, LHA $(-42 \% ; 41 \pm 1$ vs. $71 \pm 2 ; \mathrm{P}<0.001)$ and posterior hypothalamic area $(-68 \% ; 74 \pm 2$ vs. $228 \pm 14 ; \mathrm{P}<0.001)$ as compared with group $\mathrm{C}$, however, there was an increase at P90 (Fig. 4C). By contrast, in the UN group at P14, there was an increase in D2 receptor expression in the ARC $(+80 \% ; 124 \pm 1$ vs. $69 \pm 2 ; \mathrm{P}<0.001)$, although no differences were observed at P90 (Fig. 4D).

\section{Discussion}

Results of the current study present three novel observations. First, data demonstrate that the prenatal UN group negatively impacted development of the offspring (UN), however,

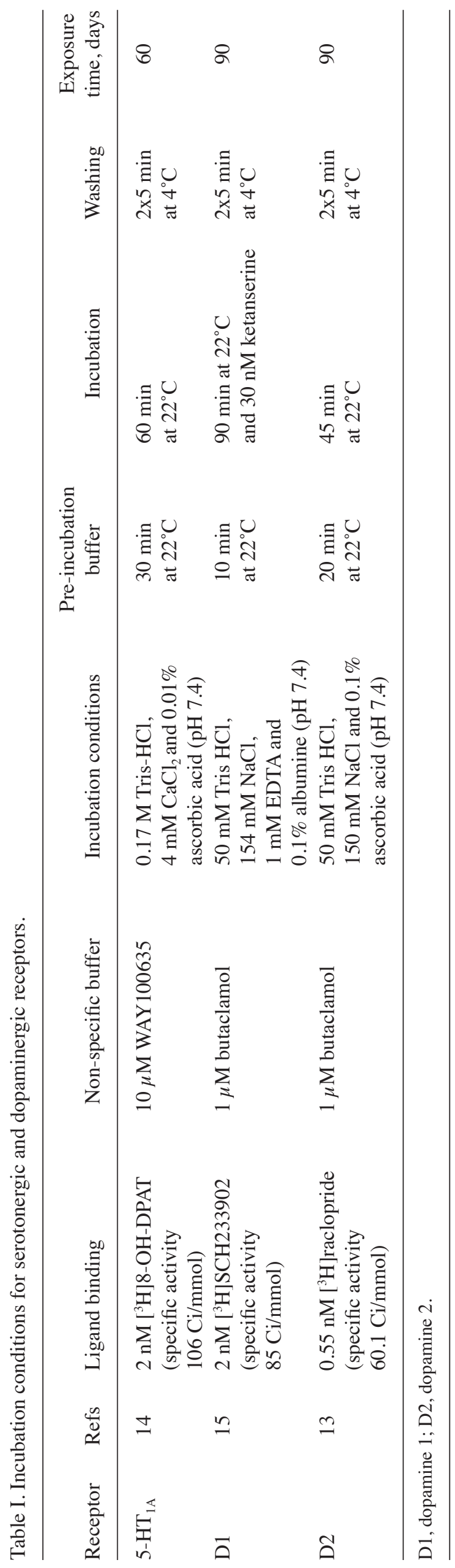




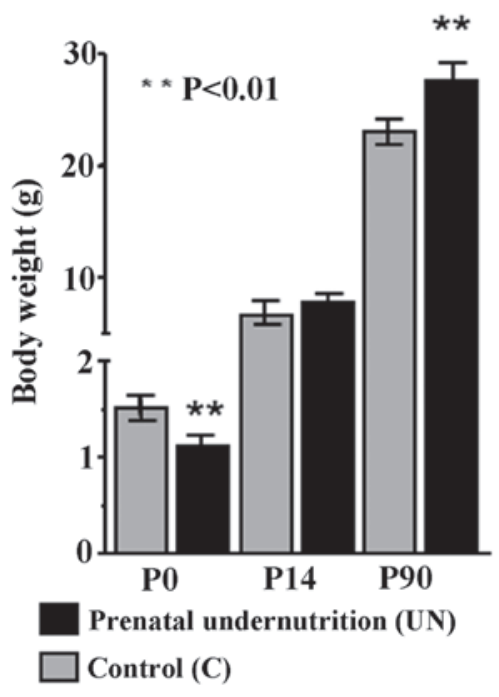

Figure 1. Representation of body weight in prenatal UN vs. C groups on postnatal days $0(\mathrm{P} 0), 14$ (P14) and 90 (P90). Data are expressed as mean \pm SEM; $\mathrm{n}=10 /$ group. ${ }^{* *} \mathrm{P}<0.01$, vs. C. C, control; $\mathrm{UN}$, undernutrition; $\mathrm{P}$, postnatal.



Figure 2. Postweaning food intake of male offspring between 21 and 90 days-old in $\mathrm{C}$ and prenatal $\mathrm{UN}$ groups ( $\mathrm{n}=10$ per group from 6 litters). ${ }^{*} \mathrm{P}<0.05$, vs. C. C, control; UN, undernutrition.

following birth the rate and timing of postnatal catch-up growth played critical and significant roles. Second, accelerated body weight gain continued following weaning and was associated with altered anorexigenic regulatory mechanisms (leptin receptor). The data also show that developmental adaptation ensures fetal survival of the $5 \mathrm{HT}_{1 \mathrm{~A}}, \mathrm{D} 1$ and D2 receptors in the hypothalamus. These observations emphasize the plasticity and potential of critical appetite-regulating neurotransmitters in the pathogenesis of fetal programming-induced obesity.

Fetal programming corresponded to an attempt of the fetus to adapt to the adverse conditions encountered in utero (9). These adaptations are likely to be beneficial if the conditions prevail later in life but become detrimental for normal or plentiful nutrition, favoring the appearance of obesity. Furthermore, the environment encountered during fetal life and infancy is significantly associated with the risk of diseases in adult life (16). Thus, UN during pregnancy is involved in the programming of offspring for the develop-

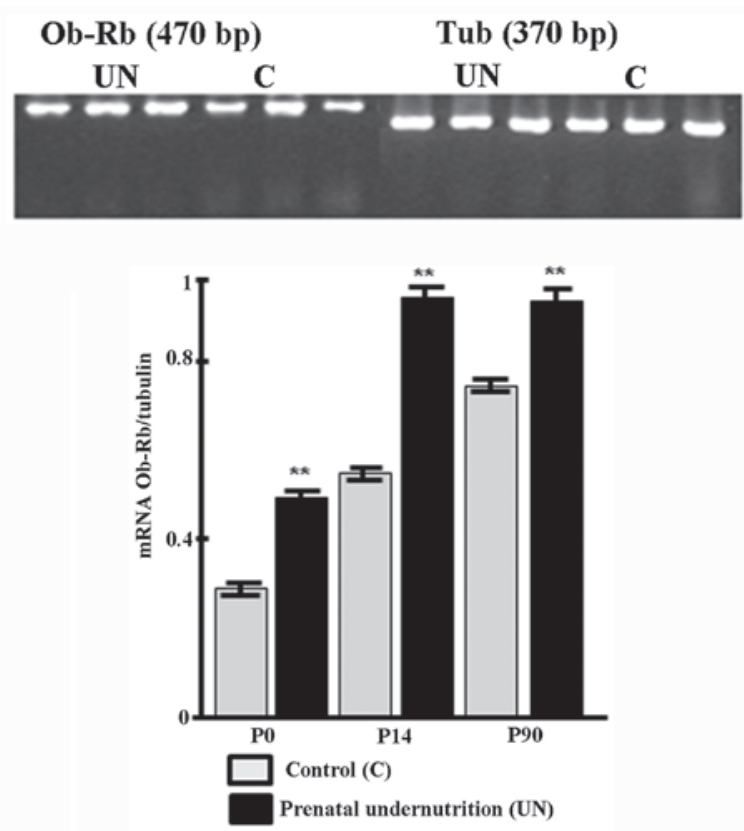

Figure 3. Changes in mRNA expression of $\mathrm{Ob}-\mathrm{Rb}$ in the hypothalamus at postnatal days 0 (P0), 14 (P14) and 90 (P90) in UN and C groups and representation of $\mathrm{Ob}-\mathrm{Rb}$ in $2 \%$ agarose gels in the presence of ethidium bromide. ${ }^{* *} \mathrm{P}<0.01$, vs. C. C, control; UN, undernutrition; P, postnatal.

ment of obesity and diabetes (17). To explain these causal relationships, it has been suggested that adaptations during the critical phases of growth and development may ensure the maintenance of homeostasis. Therefore, survival when the environment is compromised. Studies exploring the 'thrifty phenotype' hypothesis in animal models have indicated that long-term obesity and disease risk markers may be programmed by alterations in maternal nutrition, for example protein restriction (18-20) or by reduced nutritional supply to the fetus by uterine artery ligation in late pregnancy $(18,19)$. In addition, maternal high-fat diet consumption during gestation, independent of obesity, increases the risk of offspring developing behavioral disorders, including anxiety.

In pregnant mice, production of serotonin and the expression of tryptophan hydroxylase 1 (Tph1), the rate-limiting enzyme in the synthesis of the 5HT pathway, were highly elevated in $\beta$-cells. Similar elevation in the expression of the Gaq protein coupled 5HT receptor gene, Htr2b, was also noted. Moreover, inhibition of Tph1 or Htr2b blocked normal increase of $\beta$-cell mass during pregnancy and resulted in glucose intolerance in mice $(18,21)$.

Thus, current evidence has demonstrated that the ghrelin orexigenic effect is mediated by the selective modulation of hypothalamic fatty acid metabolism $(18,22)$. Moreover, ob/ob mice exhibited reductions in food intake and body weight when treated with D1 and D2 agonists $(18,23)$.

In the present study, exposure to maternal food restriction during gestation resulted in LBW offspring. However, with ad libitum feeding during early postnatal life, mice recovered their body weight by P14. In the hypothalami, the VMH, LHA and several other hypothalamic nuclei are well established as centers for metabolism regulation and have potent modulator effects on daily food intake mediated primarily via lower brainstem nuclei $(18,24-26)$. 
A



B

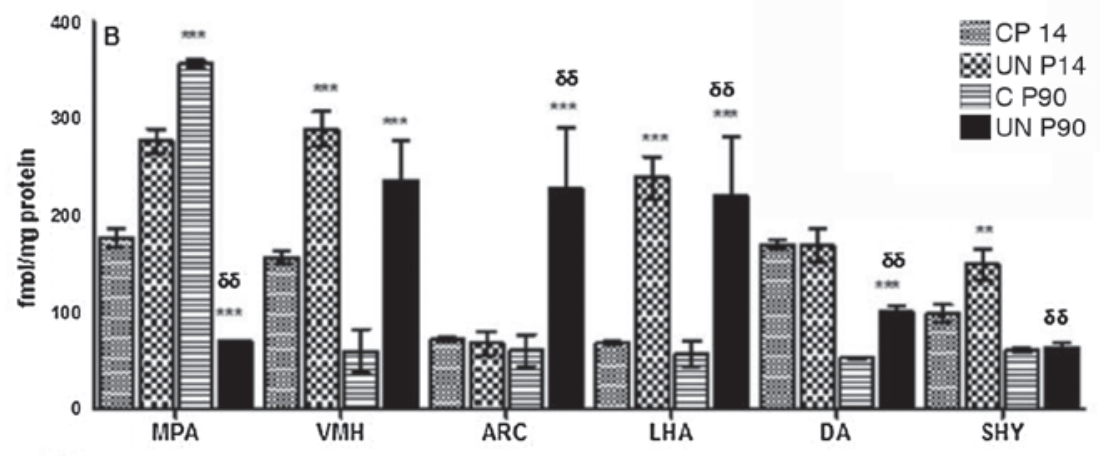

$\mathbf{C}$

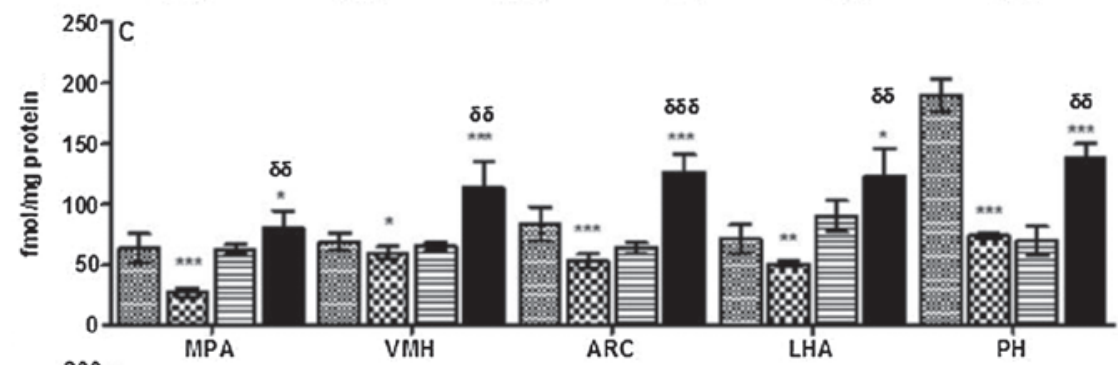

D

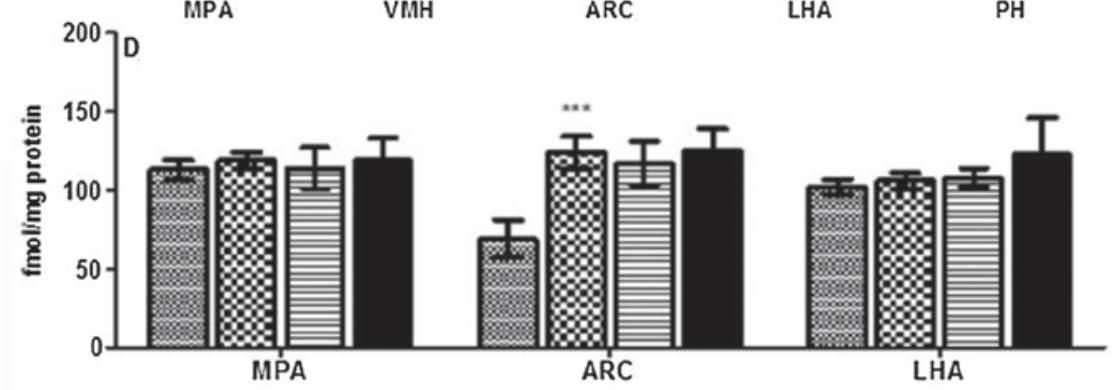

Figure 4. Autoradiographic distribution of 5. (A) Representation in brain of 5-HT1A; (B) 5-HT1A with [ $\left.{ }^{3} \mathrm{H}\right] 8-\mathrm{OH}-\mathrm{DPAT}$ binding (fmol/mg protein); (C) distribution of D1 with $\left[{ }^{3} \mathrm{H}\right] \mathrm{SCH} 23390$ binding (fmol/mg protein); and (D) distribution of D2 [ $\left.{ }^{3} \mathrm{H}\right] \mathrm{raclopride}$ binding (fmol/mg protein) in the hypothalamus of mice. ${ }^{*} \mathrm{P}<0.05,{ }^{* *} \mathrm{P}<0.01$ and ${ }^{* * *} \mathrm{P}<0.001$, UN vs. control; ${ }^{\circledR} \mathrm{P}<0.05,{ }^{\delta} \mathrm{P}<0.01$ and ${ }^{\delta \delta} \mathrm{P}<0.001$, UN $\mathrm{P} 14$ vs. UN P90 offspring. CP14, control; UN, undernutrition. P, postnatal; D1, dopamine 1; D2, dopamine 2.

In the group of UN mice in the present study, food intake was increased and the group demonstrated hyperphagia. In addition, the 5- $\mathrm{HT}_{1 \mathrm{~A}}$ receptor was elevated in $\mathrm{VMH}$ and $\mathrm{LHA}$ at $\mathrm{P} 14$ and P90, but was reduced in the ARC, indicating a decrease in $5-\mathrm{HT}_{1 \mathrm{~A}}$. This was directly associated with negative regulation of food intake, indicating hyperphagia associated with fetal programming. Previous studies have shown that agents that mimic or enhance 5-HT activity produced hypophagia (27) and weight loss, and inhibited neuropeptide $\mathrm{Y}$ (NPY) neuronal activity. In addition, drugs that block 5-HT release, stimulate feeding and NPY $(28,29)$.

Results of this study suggest that 5-HT may tonically inhibit NPY neurons and mediate the effects of 5-HT serotonin on energy homeostasis in the ARC. The present study indicates that the $5-\mathrm{HT}_{1 \mathrm{~A}}$ receptor is likely to modify the regulation between the NPY and 5-HT system in the ARC during LBW, with an impact on adult life. Moreover, during neonatal development, food intake must be maximized to support growth, yet plasma leptin levels are relatively high. These high levels of leptin during the postnatal period have been reported in rats and mice. Similarly, Ob-Rb receptor expression was increased in the hypothalamus. Little is known about the co-regulation of $\mathrm{Ob}-\mathrm{R}$ and $\mathrm{Ob}-\mathrm{Rb}$ gene expression, receptor number or the impact of receptor regulation on leptin sensitivity (12). In this study, Ob-Rb receptor expression was increased with hyperphagia in mice with prenatal UN and an increase of food intake in early postnatal life.

Previous studies (30) have shown the importance of leptin and its association with dopamine in the modulation of food intake. In the present study, the D1 receptor was reduced in the hypothalamic nuclei in the UN group at P14. However, the D1 receptor at P90 was increased, which was important in ARC since these have been involved in metabolic changes. Thus, if dopaminergic receptor expression in the hypothalamus is 
controlled by dopamine release, it is possible that upregulation of the D1 receptor mRNA in the VMH and a decrease in the LHA of obese rats may be due to a low or high local dopamine concentration, respectively $(31,32)$. In addition, alterations in D2 receptor levels were compared in Zucker obese (fa/fa) and lean $(\mathrm{Fa} / \mathrm{Fa})$ rats at 1 and 4 months of age, respectively, under two varying feeding conditions (restricted and unrestricted food access) using in vivo PET imaging and in vitro autoradiography. D2 receptors were higher at 1 than at 4 months of age and that food-restricted animals had higher D2 receptor levels than unrestricted animals $(31,32)$. Thus, in the present study, increased D2 receptor expression in the ARC at P14 indicated a correlation with catch-up growth following prenatal UN. More studies are required to evaluate leptin effects on brain structure, function and metabolism, and concomitantly, to provide a solid foundation for studies aiming to assess possible roles of leptin, 5-HT and dopamine in food intake and in UN.

In conclusion, prenatal UN during gestation has defined time windows with long-term effects on weight gain and metabolism. In addition, overfeeding immediately following fetal growth retardation induces catch-up growth. Therefore, hyperphagia resulting from early programming indicated changes in the dopaminergic and serotonergic system that may program a state of obesity during adulthood.

\section{Acknowledgements}

The present study was partially supported by a grant from FIS (FIS/IMSS/PROT/G11/991). The authors thank Alberto Ramirez for expert assistance.

\section{References}

1. Barker DJP, Hales CN, Fall CHD, Osmond C, Phipps K and Clark PMS: Type 2 (non-insulin-dependent) diabetes mellitus, hypertension and hyperlipidaemia (syndrome $\mathrm{X}$ ): relation to reduced fetal growth. Diabetologia 36: 62-67, 1993.

2. Fontaine KR, Redden DT, Wang C, Westfall AO and Allison DB: Years of life lost due to obesity. JAMA 289: 187-193, 2003.

3. Poston L: Developmental programming and diabetes. The human experience and insight from animal models. Best Pract Res Clin Endocrinol Metab 24: 541-552, 2010.

4. Desai M, Gayle D, Babu J and Ross GM: Programmed obesity in intrauterine growth-restricted newborns: modulation by newborn nutrition. Am J Physiol Regul Integr Comp Physiol 288: R91-R96, 2005.

5. Hokken-Koelega AC, De Ridder MA, Lemmen RJ, Den Hartong H, De Muinck Keizer-Schrama SM and Drop SL: Children born small for gestation age: do they catch up? Pediatr Res 38: 267-271, 1995.

6. Jones AP, Simson EL and Friedman MI: Gestational undernutrition and the development of obesity in rats. J Nutr 114: 1484-1492, 1984.

7. Vickers MH, Breier BH, Cutfield WS, Hofman PL and Gluckman PD: Fetal origin of hyperphagia, obesity, and hypertension and postnatal amplification by hypercaloric nutrition. Am J Physiol Endocrinol Metab 279: E83-E87, 2000.

8. Begum G, Stevens A, Smith EB, Connor K, Challis JR, Bloomfield $\mathrm{F}$ and White A: Epigenetic changes in fetal hypothalamic energy regulating pathways are associated with maternal undernutrition and twinning. FASEB J 26: 1694-1703, 2012.

9. Tamashiro K and Moran T: Perinatal environment and its influences on metabolic programming of offspring. Physiol Behav 100: 560-566, 2010.

10. Berger MA, Barros VG, Sarchi MI, Tarazi FI and Antonelli MC: Long-term effects of prenatal stress on dopamine and glutamate receptors in adult rat brain. Neurochem Res 27: 1525-1533, 2002 .
11. Pôrto LC, Sardinha FL, Telles MM, Guimarães RB, Albuquerque KT, Andrade IS, Oyama LM, Nascimento CM, Santos OF and Ribeiro EB: Impairment of the serotonergic control of feeding in adult female rats exposed to intrauterine malnutrition. Br J Nutr 101: 1255-1261, 2009.

12. Manuel-Apolinar L, Zarate A, Rocha L and Hernández M: Fetal malnutrition affects hypothalamic leptin receptor expression after birth in male mice. Arch Med Res 41: 240-245, 2010.

13. Bauer A, Zilles K, Matusch A, Holzmann C, Riess O and von Hörsten S: Regional and subtype selective changes of neurotransmitter receptor density in a rat transgenic for the Huntington's disease mutation. J Neurochem 94: 639-650, 2005.

14. Luna-Munguía H, Manuel-Apolinar L, Rocha L and Meneses A: 5-HT1A receptors expression during memory formation. Psychopharmacol 181: 309-318, 2005.

15. Díaz-Romero M, Arias-Montaño JA, Eguibar JR and Flores G: Enhanced binding of dopamine D1 receptors in caudate putamen subregions in High-Yawning Sprague-Dawley rats. Synapse 56: 69-73, 2005.

16. Harder T, Rodekamp E, Schellong K, Dudenhausen JW and Plagemann A: Birth weight and subsequent risk of type 2 diabetes: a meta-analysis. Am J Epidemiol 165: 849-857, 2007.

17. Stevens A, Begum G and White A: Epigenetic changes in the hypothalamic pro-opiomelanocortin gene: a mechanism linking maternal undernutrition to obesity in the offspring? Eur J Pharmacol 660: 194-201, 2011.

18. Hales $\mathrm{CN}$ and Barker DJP: The thrifty phenotype hypothesis. $\mathrm{Br}$ Med Bull 60: 5-20, 2001.

19. Ozanne SE,Lewis R, Jennings BJ and Hales $\mathrm{CN}$ : Early programming of weight gain in mice prevents the induction of obesity by a highly palatable diet. Clin Sci (Lond) 106: 141-145, 2004.

20. Jousse C, Parry L, Lambert-Langlais S, Maurin AC, Averous J, Bruhat A, Carraro V, et al: Perinatal undernutrition affects the methylation and expression of the leptin gene in adults: implication for the understanding of metabolic syndrome. FASEB J 25: 3271-3278, 2011.

21. Kwak SH, Park BL, Kim H, German MS, Go MJ, Jung HS, et al: Association of variations in TPH1 and HTR2B with gestational weight gain and measures of obesity. Obesity (Silver Spring) 20: 233-238, 2012.

22. Lage R, Vázquez MJ, Varela L, Saha AK, Vidal-Puig A, Nogueiras R, Diéguez C and López M: Ghrelin effects on neuropeptides in the rat hypothalamus depend on fatty acid metabolism actions on BSX but not on gender. FASEB J 24: 2670-2679, 2010.

23. Bina KG and Cincotta AH: Dopaminergic agonists normalize elevated hypothalamic neuropeptide $\mathrm{Y}$ and corticotropin-releasing hormone, body weight gain, and hyperglycemia in ob/ob mice. Neuroendocrinol 71: 68-78, 2000.

24. Schwartz MW, Woods SC, Porte D Jr, Seeley RJ and Baskin DG: Central nervous system control of food intake. Nature 404: 661-671, 2000.

25. Davis JD and Smith GP: Learning to sham feed: behavioral adjustments to loss of physiological postingestional stimuli. Am J Physiol 259: R1228-R1235, 1990.

26. Smith GP: The controls of eating: a shift from nutritional homeostasis to behavioral neuroscience. Nutrition 16: 814-820, 2000.

27. Schellekens H, Clarke G, Jeffery IB, Dinan TG and Cryan JF: Dynamic 5-HT2C receptor editing in a mouse model of obesity. PLos One 7: e32266, 2012.

28. Dryden S, Burns SJ, Frankish HM and Williams G: Increased hypothalamic neuropeptide Y concentration or hyperphagia in streptozotocin-diabetic rats are not mediated by glucocorticoids. Eur J Pharmacol 340: 221-225, 1997.

29. Dryden S, Pickavance L, Frankish HM and Williams G: Increased neuropeptide $\mathrm{Y}$ secretion in the hypothalamic paraventricular nucleus of obese (fa/fa) Zucker rats. Brain Res 690: 185-188, 1995.

30. Pfaffly J, Michaelides M, Wang GJ, Pessin JE, Volkow ND and Thanos PK: Leptin increases striatal dopamine D2 receptor binding in leptin-deficient obese (ob/ob) mice. Synapse 64: 503-510, 2010.

31. Sullivan EL, Smith MS and Grove KL: Perinatal exposure to high-fat diet programs energy balance, metabolism and behavior in adulthood. Neuroendocrinology 93: 1-8, 2011.

32. Sullivan EL, Grayson B, Takahashi D, Robertson N, Maier A, Bethea CL, Smit MS, Coleman K and Grove KL: Chronic consumption of a high-fat diet during pregnancy causes perturbations in in the serotonergic system and increased anxiety-like behavior in nonhuman primate offspring. J Neurosci 30: 3826-3830, 2010. 